U.S. Geological Survey

U.S. Department of the Interior

Prepared in cooperation with the

\title{
Sedimentation Survey of Lago Dos Bocas, Puerto Rico, October 1999
}

Water-Resources Investigations Report 00-4234

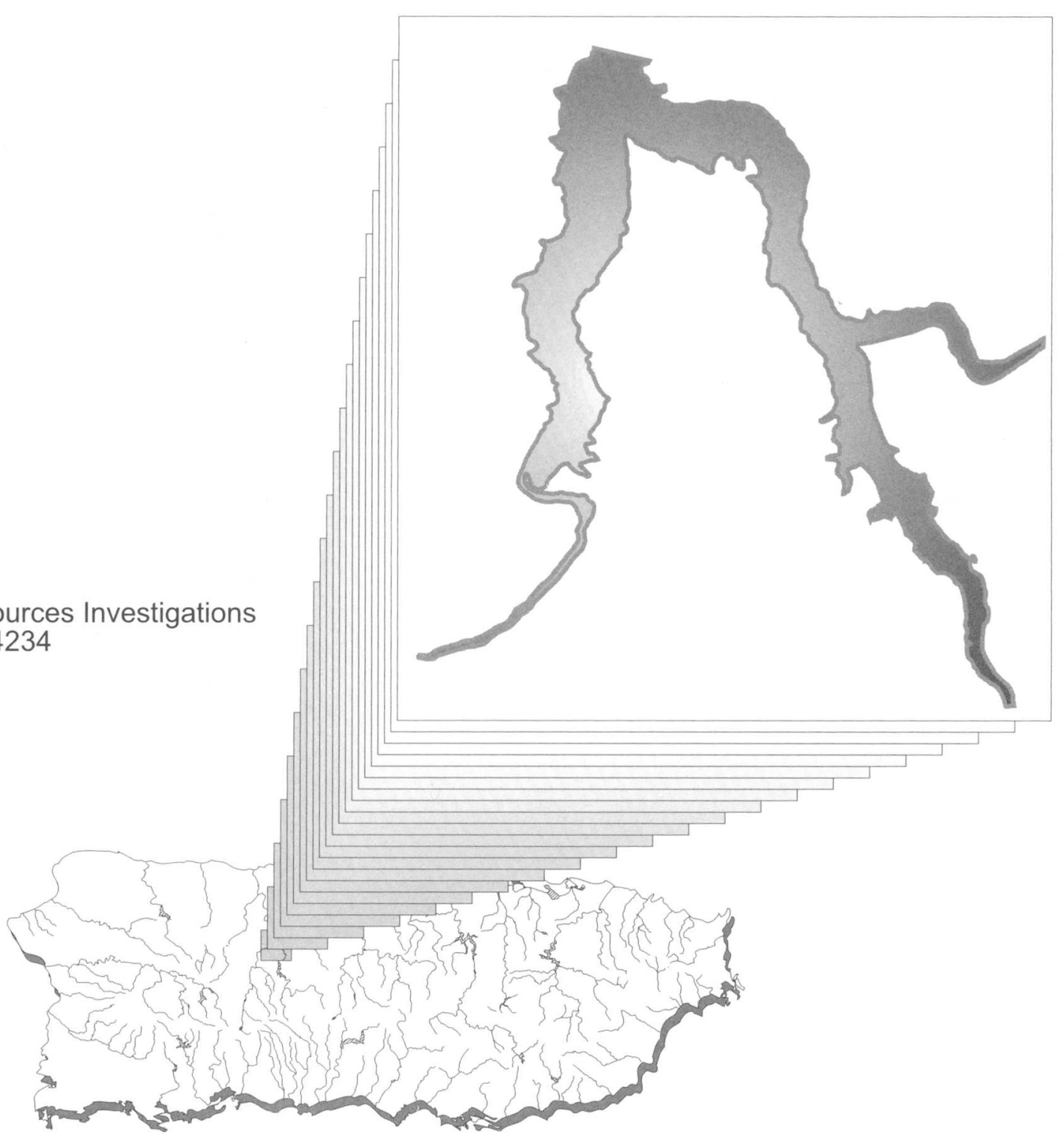





\section{Sedimentation Survey of Lago Dos Bocas, Puerto Rico, October 1999}

By Luis R. Soler-López

Water-Resources Investigations Report 00-4234

In cooperation with the

PUERTO RICO AQUEDUCT AND SEWER AUTHORITY 


\section{U.S. DEPARTMENT OF THE INTERIOR \\ BRUCE BABBITT, Secretary}

\section{U.S. GEOLOGICAL SURVEY}

Charles G. Groat, Director

Use of trade names in this report is for identification purposes only and does not imply endorsement by the U.S. Government.

For additional information write to:

District Chief

U.S. Geologic al Survey

GSA Center, Suite 400-15

651 Federal Drive

Guaynabo, Puerto Rico 00965
Copies of this report can be purchased from:

U.S. Geological Survey .

Branch of Information Services

Box 25286

Denver, CO 80225 


\section{CONTENTS}

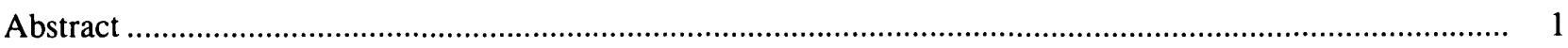

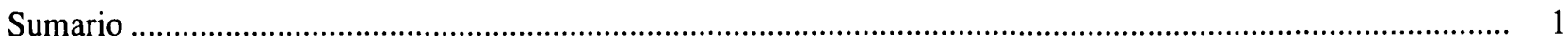

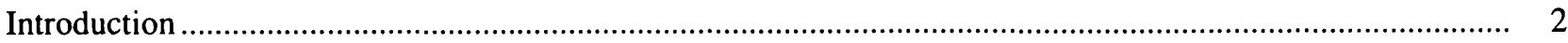

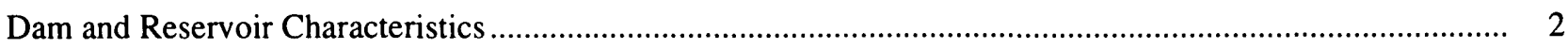

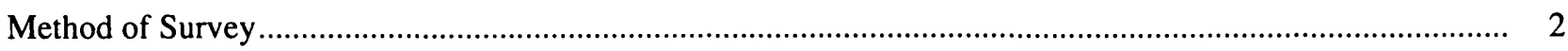

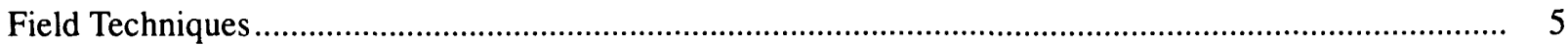

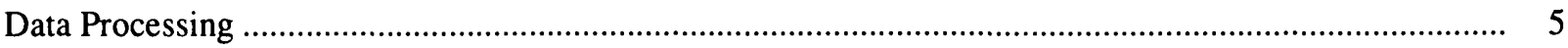

Actual Capacity and Sediment Accumulation ..................................................................................... 9

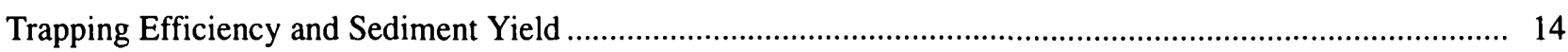

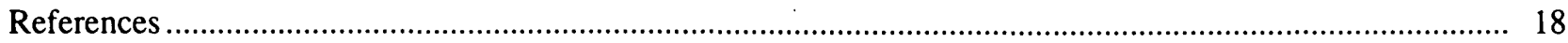

\section{PLATE}

[Plate is in pocket]

1. Lago Dos Bocas, Puerto Rico, Bathymetry, October 1999 


\section{FIGURES}

1.-4. Map showing

1. Location of Lago Dos Bocas in the Río Grande de Arecibo basin, Puerto Rico

2. Planned cross-section locations for the October 1999 bathymetric survey of Lago Dos Bocas, Puerto Rico.

3. Actual track lines of the October 1999 bathymetric survey of Lago Dos Bocas, Puerto Rico

4. Reference distances for longitudinal profiles of Lago Dos Bocas, Puerto Rico, during the 1994, 1997, and 1999 bathymetric surveys

5. Selected cross-section profiles generated from the TIN surface model of Lago Dos

Bocas, Puerto Rico, based on 1994, 1997, and 1999 bathymethic surveys

6. Comparison of longitudinal depth profiles for 1994, 1997, and 1999 along the Río Grande de Arecibo, Río Caonillas, and Río Limón branches of Lago Dos Bocas, Puerto Rico

7. Graph showing lake elevation-storage capacity curves for Lago Dos Bocas, Puerto Rico, for 1994,1997 , and 1999

8. Storage capacity to inflow relation established by Brune in 1953

\section{TABLES}

1. Principal characteristics of Lago Dos Bocas and Dos Bocas Dam, Puerto Rico

2. Summary of the 1994, 1997, and 1999 bathymetric survey results, Lago Dos Bocas, Puerto Rico..

3. Available storage capacity, as a function of lake elevation, for Lago Dos Bocas, Puerto Rico, October 1999. 


\begin{tabular}{|c|c|c|}
\hline Multiply & By & To obtain \\
\hline \multicolumn{3}{|c|}{ Length } \\
\hline centimeter & 0.03281 & foot \\
\hline meter & 3.281 & foot \\
\hline kilometer & 0.6214 & mile \\
\hline \multicolumn{3}{|c|}{ Area } \\
\hline square meter & 10.76 & square foot \\
\hline square kilometer & 0.3861 & square mile \\
\hline square kilometer & 247.1 & acre \\
\hline \multicolumn{3}{|c|}{ Volume } \\
\hline cubic meter & 35.31 & cubic foot \\
\hline cubic meter & 0.0008107 & acre-foot \\
\hline million cubic meters & 810.7 & acre-foot \\
\hline \multicolumn{3}{|c|}{ Volume per unit time (includes flow) } \\
\hline cubic meter per second & 35.31 & cubic feet per second \\
\hline cubic meter per second & 15,850 & gallon per minute \\
\hline cubic meter per second & 22.83 & million gallons per day \\
\hline cubic meter per year & .000811 & acre-foot per year \\
\hline \multicolumn{3}{|c|}{ Mass per area (includes sediment yield) } \\
\hline gram per cubic centimeter & 62.43 & pound per cubic foot \\
\hline kilogram per square kilometer & 0.002855 & ton per square mile \\
\hline megagram per square kilometer & 2.855 & ton per square mile \\
\hline \multicolumn{3}{|c|}{ Mass per area (includes sediment yield) } \\
\hline megagram per year & 4.41 & ton per year \\
\hline
\end{tabular}

\section{Datums}

Horizontal Datum - Puerto Rico Datum, 1940 Adjustment

Sea level: In this report, "sea level" refers to the National Geodetic Vertical Datum of 1929 (NGVD of 1929)—a geodetic datum derived from a general adjustment of the first-order level nets of the United States and Canada, formerly called "Seal Level Datum of 1929".

\section{Acronyms used in this report}

BLASS Bathymetric/Land Survey System

DGPS Differential Global Positioning System

GIS Geographic Information System

PRASA Puerto Rico Aqueduct and Sewer Authority

TIN Triangulated Irregular Network

USGS U.S. Geological Survey 



\title{
Sedimentation Survey of Lago Dos Bocas, Puerto Rico, October 1999
}

\author{
By Luis R. Soler-López
}

Abstract

Lago Dos Bocas has been losing storage capacity at a historical sedimentation rate of about 309,000 cubic meters per year (1942 to 1985).

The long-term sedimentation rates have increased to about 311,000 cubic meters per year in 1994, 314,000 cubic meters per year in 1997 , and 341,000 cubic meters per year in 1999. The increase in long-term sedimentation rates between 1994 and 1999 are primarily the result of heavy rainfall and land erosion associated with Hurricane Hortense in September 1996 and Hurricane Georges in September 1998. Fifty-two percent of the original storage capacity has been lost because of sediment accumulation between 1942 and 1999. The Lago Dos Bocas storage capacity decreased from 21.31 million cubic meters in 1994 to 20.23 million cubic meters in 1997 , and to 18.04 million cubic meters in 1999 , or about 15 percent since 1994. At this stormaccelerated sedimentation rate, the reservoir is expected to fill with deposited material by the year 2052.

Based on the capacity/inflow ratio, the estimated trapping efficiency of Lago Dos Bocas decreased from about 78 percent in 1997 to about 73 percent in 1999. The estimated sediment yield of the Lago Dos Bocas drainage area (excluding the drainage area above the Lago Caonillas Dam) increased from 1,299 megagrams per year in 1997 to 1,377 megagrams per year in 1999 .

\section{Sumario}

El Lago Dos Bocas ha estado perdiendo su capacidad de almacenamiento a una taza de sedimentación histórica de unos 309,000 metros cúbicos al año (de 1942 a 1985). Las tazas de sedimentación a largo plazo han aumentado a unos 311,000 metros cúbicos al año en 1994, 314,000 metros cúbicos al año en 1997 y 341,000 metros cúbicos al año en 1999. El aumento de sedimentación entre 1994 y 1999 se debe principalmente a las fuertes lluvias y a la erosión del terreno asociados al huracán Hortense en septiembre de 1996 y al huracán Georges en septiembre de 1998. Se ha perdido 52 por ciento de la capacidad de almacenamiento original debido a la acumulación de sedimento entre 1942 y 1999. La capacidad de almacenamiento del Lago Dos Bocas ha disminuido de 21.31 millones de metros cúbicos en 1994 a 20.23 millones de metros cúbicos en 1997 y a 18.04 millones de metros cúbicos en 1999 (alrededor de 15 por ciento) desde 1994. A esta taza de sedimentación acelerada por las tormentas, se esperaría que el embalse se llenara de material depositado para el año 2052.

Basados en la relación de capacidad/ afluente, la eficiencia estimada para atrapar sedimento del Lago Dos Bocas disminuyó de un 78 por ciento en 1997 a un 73 por ciento en 1999. El rendimiento de sedimento estimado del área de drenaje del Lago Dos Bocas (excluyendo el área de drenaje aguas arriba de la represa del Lago Caonilllas) aumentó de 1,299 megagramos al año en 1997 a 1,377 megagramos al año en 1999. 


\section{INTRODUCTION}

Lago Dos Bocas is an integral part of the Puerto Rico Aqueduct and Sewer Authority (PRASA) Superaqueduct Project. Plans are to utilize water released during hydroelectric power generation at the reservoir dam and capture the releases in a retention pond constructed on the Río Grande de Arecibo below the dam. The captured water will then be used to supply potable water for north coast residents of the island of Puerto Rico. The project's success depends on the available storage capacity of the reservoir.

Recent decreases in storage capacity have constrained the original project plans. The passage of Hurricane Hortense during September 1996 brought torrential rains and extensive land erosion that reduced the storage capacity of the reservoir by about 1.08 million cubic meters, since the previous bathymetric survey in August 1994. Two years later, during September 1998, Hurricane Georges passed over the island of Puerto Rico and generated even more rainfall than Hurricane Hortense. The rains transported large amounts of sediments into the reservoir, presumably further reducing the storage capacity of the reservoir.

During October 1999, the U.S. Geological Survey (USGS), in cooperation with PRASA, conducted a bathymetric survey of Lago Dos Bocas to assess the impact of Hurricane Georges on the storage capacity of the reservoir. Data on position and water depth were simultaneously collected using a Differential Global Positioning System (DGPS) coupled to a depth sounder. The collected data were stored in digital form and then transferred into a Geographic Information System (GIS) for processing and analysis. The GIS was then used to calculate the existing storage capacity, the amount and location of sediment deposition, and the sedimentation rate of the reservoir as of October 1999.

\section{DAM AND RESERVOIR CHARACTERISTICS}

Lago Dos Bocas reservoir was completed in 1942. The reservoir was built to provide water for hydroelectric power generation. The dam is located about 9 kilometers northeast of the town of Utuado, directly downstream of the original confluence of the Río Grande de Arecibo and the Río Caonillas (fig. 1). North of the dam, Río Grande de Arecibo meanders approximately 16 kilometers through karst terrain, crosses the coastal plain and discharges into the Atlantic Ocean. The dam and powerplant form the Dos Bocas Hydroelectric Project. The reservoir originally: provided about 37.5 million cubic meters of storage capacity at a spillway elevation of 89.92 meters above mean sea level (Sheda and Legas, 1968). A three-unit powerplant is located on the right bank of the dam, adjacent to the right spillway training wall. The. spillway is an ungated overflow structure with a crest length of 110 meters. The principal characteristics of Lago Dos Bocas and the reservoir structures are presented in table 1 .

\section{METHOD OF SURVEY}

The bathymetric survey of Lago Dos Bocas included planning, data collection, data processing, and analysis. A GIS, Arc/Info (by Environmental Systems Research Institute (ESRI), Inc., 1992) was used to plan the survey lines and to analyze the bathymetric data. Cross-section locations were planned to match the 1997 survey lines. Additional survey lines were collected to increase the number of survey lines, densifying the data points, and thereby enhance survey resolution. Data were collected using a DGPS interfaced to a depth sounder. The soundings were subsequently adjusted to represent depths below the spillway elevation. Depth contours were drawn manually at 2-meter intervals. Additional contours were added to characterize the deepest and shallowest parts of the reservoir. Contour lines were then converted into a digital surface model by creating a triangulated irregular network (TIN). The TIN represents the reservoir bottom as thousands of adjoining triangles with $\mathrm{x}, \mathrm{y}$, and $\mathrm{z}$ coordinates assigned to all vertices (Environmental Systems Research Institute, Inc., 1992). The volume of the reservoir was then calculated at incremental pool elevations, and then a stage-storage curve and table were generated. For this study, GIS algorithms were used to calculate the volume of the surface model represented by the 1999 contour map. Selected cross sections and longitudinal profiles were produced from the TIN surface model of the reservoir bottom for the 1994, 1997, and 1999 bathymetric surveys. These sections were then overlain to show the amount of sediment deposition or scour at different areas of the reservoir. 


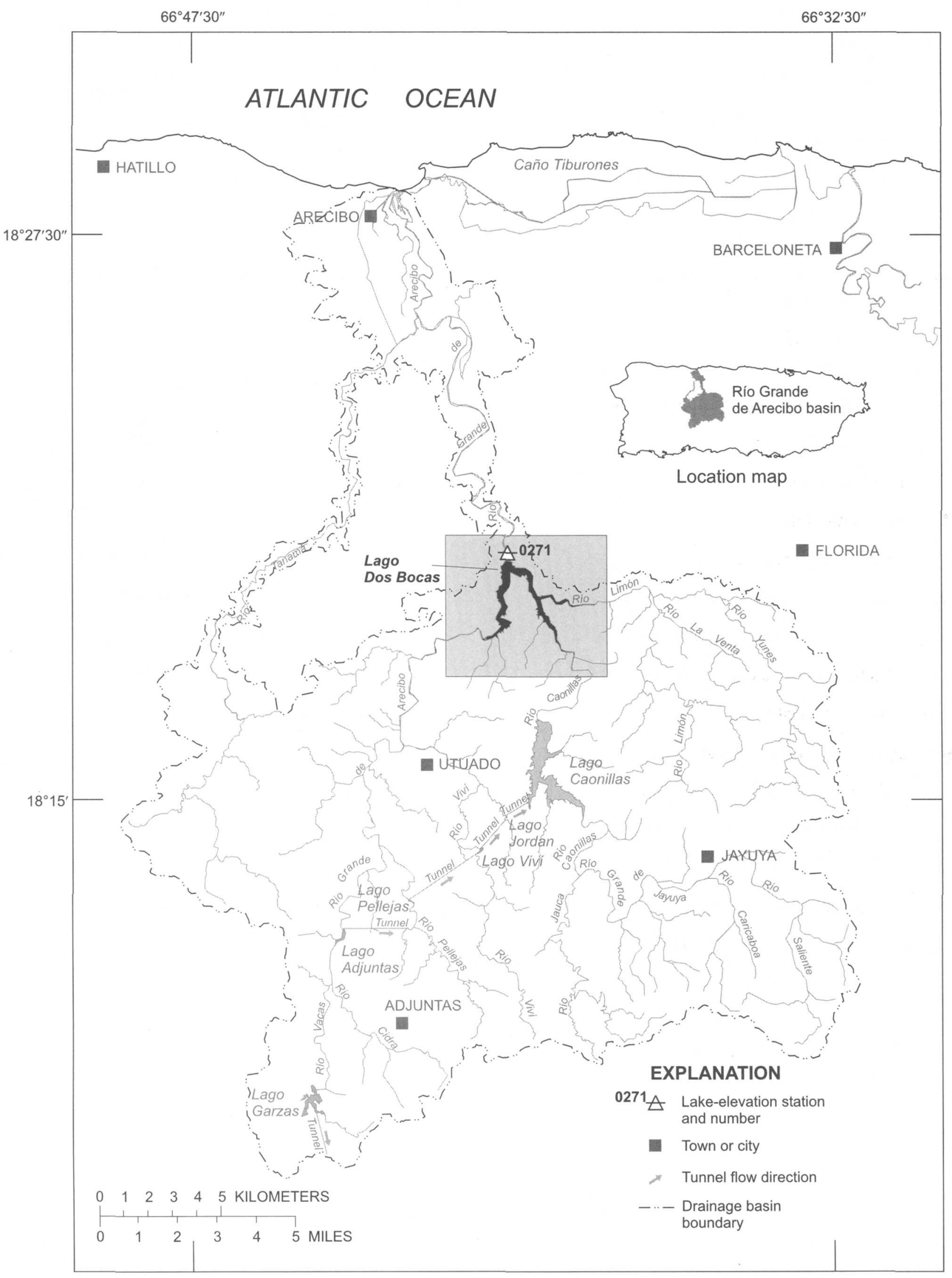

Figure 1. Location of Lago Dos Bocas in the Río Grande de Arecibo basin, Puerto Rico. 
Table 1. Principal characteristics of Lago Dos Bocas and Dos Bocas Dam, Puerto Rico (Modified from Sheda and Legas, 1968)

[Elevations in meters above mean sea level]

Total length of dam (spillway and nonoverflow sections) .401 meters

Length of spillway section .110 meters

Elevation of crest of spillway. .89 .92 meters

Maximum width of dam at base 47 meters

Diameter of penstocks. 2.74 meters

Installed power-generating capacity 22,500 kilowatts

Original maximum flood-level capacity. 61.6 million cubic meters

Design discharge at head of 8.53 meters (elevation 98.45 meters). $.5,670$ cubic meters per second

Original spillway crest-level storage 37.5 million cubic meters

Surcharge storage (flood control) .24 .1 million cubic meters

Drainage area at dam site ${ }^{1}$ .440 square kilometers

Design flooded area (elevation 88.5 meters) .2 .57 square kilometers

Maximum height of dam .57 .3 meters

Maximum original depth of normal pool .47 .2 meters

Maximum pool depth during 1999 survey. .22 .6 meters

${ }^{1}$ Includes about 130 square kilometers of Lago Caonillas drainage basin. 


\section{Field Techniques}

Data collection took place during October 5 to 7, 1999. The bathymetric survey used the Bathymetric/Land Survey System (BLASS) developed by Specialty Devices Inc. This system consists of two Novatel DGPS receivers for horizontal positioning of the survey boat. One was located at a fixed master or reference station with known coordinates and the other was installed on the survey boat to be used as the mobile unit. The benchmarks "Lookout 1997" (lat $18^{\circ} 20^{\prime} 07.073^{\prime \prime N}$., long $66^{\circ} 40^{\prime} 34.187^{\prime \prime} \mathrm{W}$.) and IGUINA (lat $18^{\circ} 19^{\prime} 30.811^{\prime \prime} \mathrm{N}$., long $66^{\circ} 39^{\prime} 20.731^{\prime \prime} \mathrm{W}$.), which were established for the 1997 bathymetric survey, were used as reference stations. The DGPS unit at the reference station sent correction signals to the DGPS unit at the survey boat every 5 seconds, to maintain the horizontal position precision of the survey boat within 2 meters. Also, if the reference station signal was obstructed by elevated land surfaces, a signal repeater was installed at a convenient location to relay signal corrections.

Reservoir depths were measured using a BLASS-MSU-IDS Intelligent Depth Sounder, which collects depth data with an accuracy of \pm 2 centimeters. The depth sounder was calibrated at water depths of 2,10 , and 16 meters. The bathymetric survey software HYPACK received and recorded water depths and geographic positions every second, while in survey mode. The collected data were stored in the computer hard disk and later transferred into the GIS.

Plans were to collect data at 41 pre-established cross sections to match most of the 1997 survey lines (fig. 2). However, additional data were collected between the original planned lines to increase the density of the data points in order to enhance the survey resolution. In 1997 , a total of 8,459 data points were collected, whereas in 1999 the number of data points was almost doubled to 15,410 . Also, random (zig-zag) data were collected in the riverine sections of the reservoir. Figure 3 shows the actual track lines where bathymetric data were collected for the October 1999 bathymetric survey of Lago Dos Bocas. The longitudinal distances from the dam to the different branches of the reservoir are shown in figure 4 .

\section{Data Processing}

Initial editing of the depth and positional data was performed within the HYPACK program. Erroneous positions were corrected by eliminating . anomalous spikes or "jumps" that appear when the correction signal from the reference station is lost for a period of time. The correction signal can be lost because of physical obstructions such as topographic features or because of electromagnetic interference. When this occurred, the erroneous positions were interpolated between the correct anterior and posterior positions. Floating debris and/or bubbles can interfere with the fathometer's transducer, causing erroneous depth readings. Depth data were corrected by interpolating between the correct anterior and posterior depth values.

The pool elevation of the reservoir changed slightly during the October 1999 bathymetric survey. To account for this change, the reservoir level was continuously monitored at the USGS reservoir-level station "Lago Dos Bocas at damsite" (no. 50027100). Then, a time-elevation correction factor was applied to transform the collected depth data to depths below the spillway elevation.

The edited data were then transferred into the GIS where contour lines were drawn and the storage capacity and sediment accumulation (volumes and rates) were calculated. Data points were color coded according to different depth ranges. Then the data points with the same color were connected and a reservoir bathymetric contour map was generated (plate 1). The contour map of the reservoir was then used to construct a TIN surface model of the reservoir. From the TIN surface model, selected cross sections representing the reservoir bottom from shore to shore and longitudinal profiles along the different branches of the reservoir were generated. 


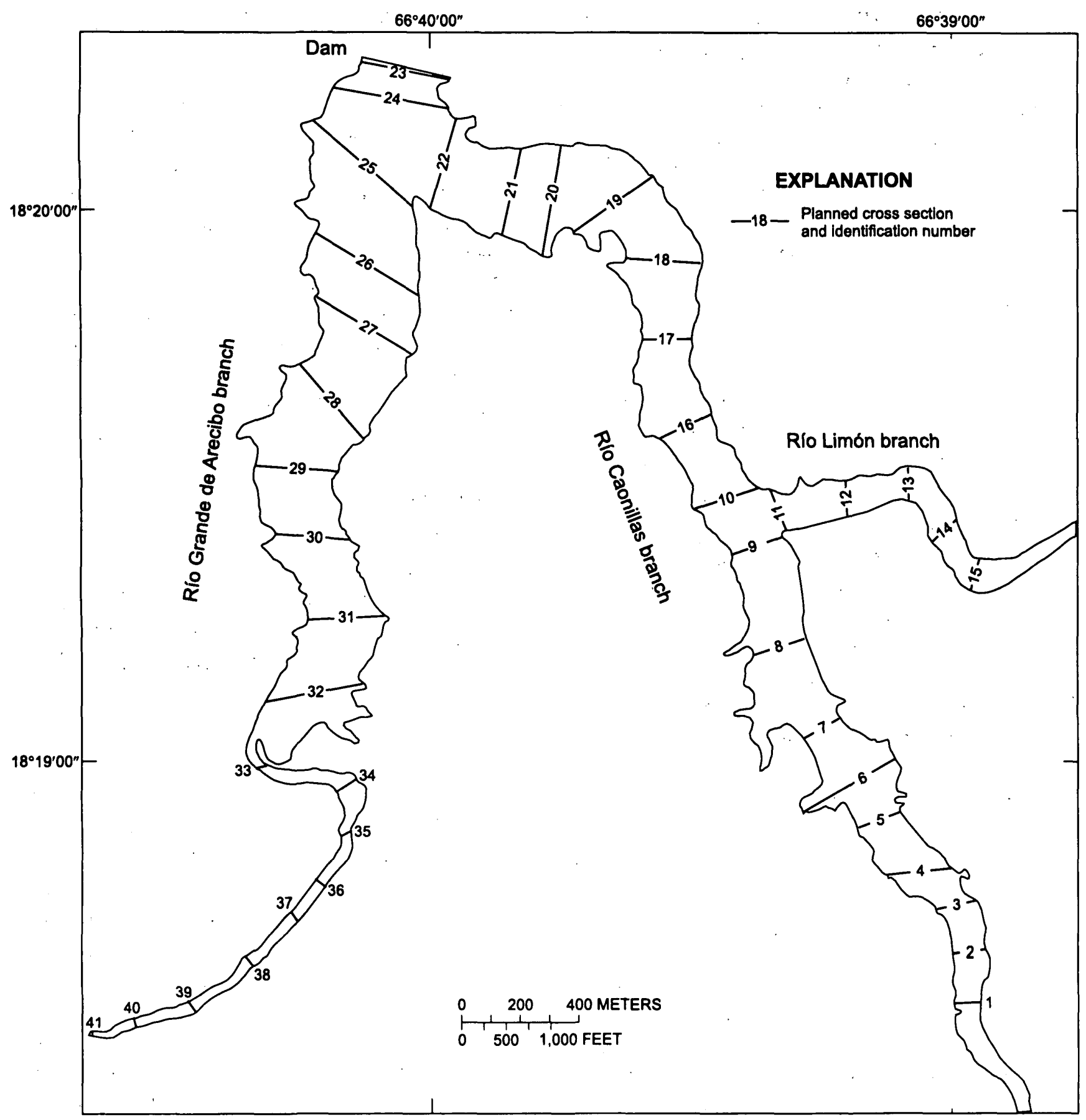

Figure 2. Planned cross-section locations for the October 1999 bathymetric survey of Lago Dos Bocas, Puerto Rico. 


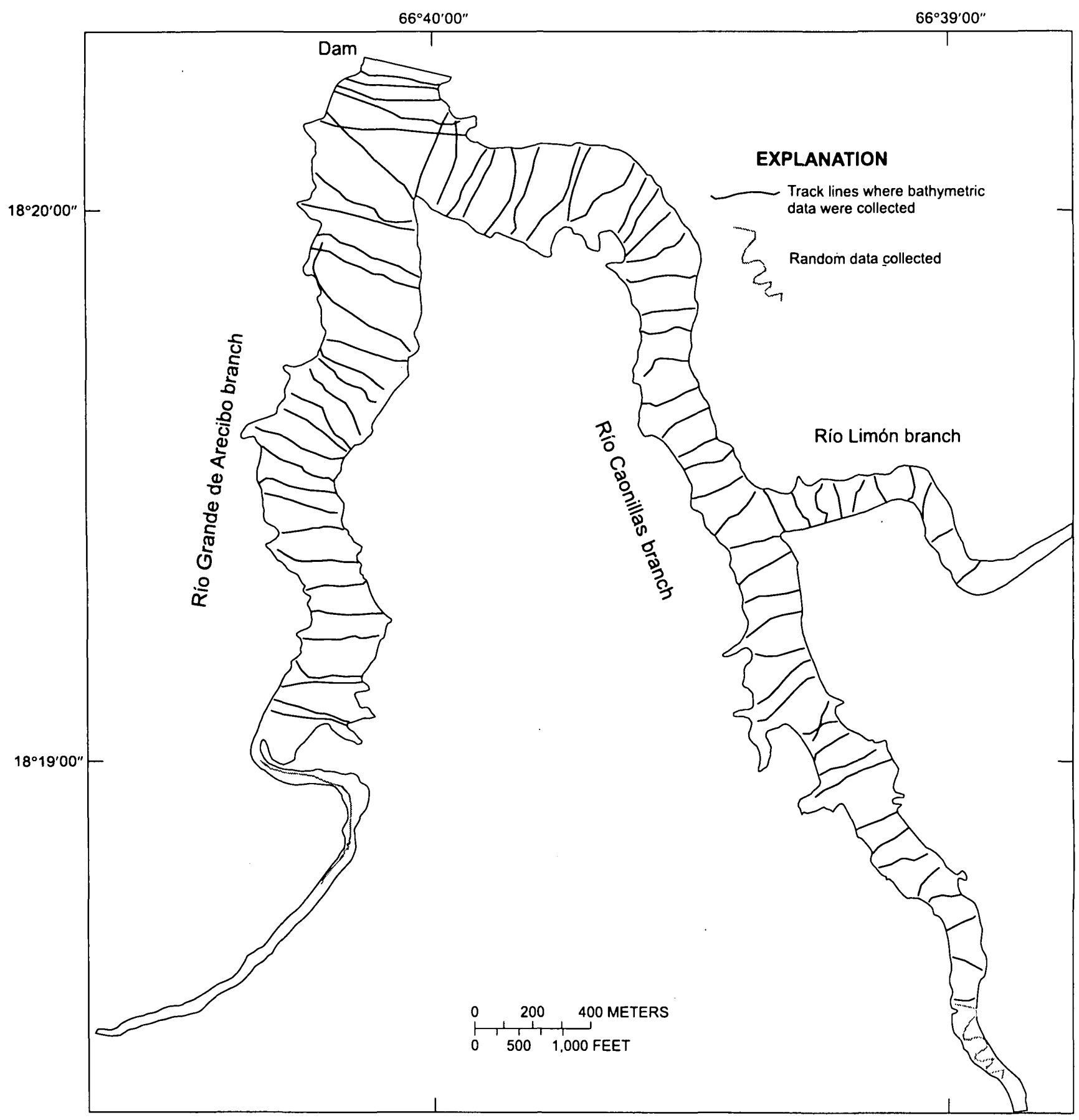

Figure 3. Actual track lines of the October 1999 bathymetric survey of Lago Dos Bocas, Puerto Rico. 


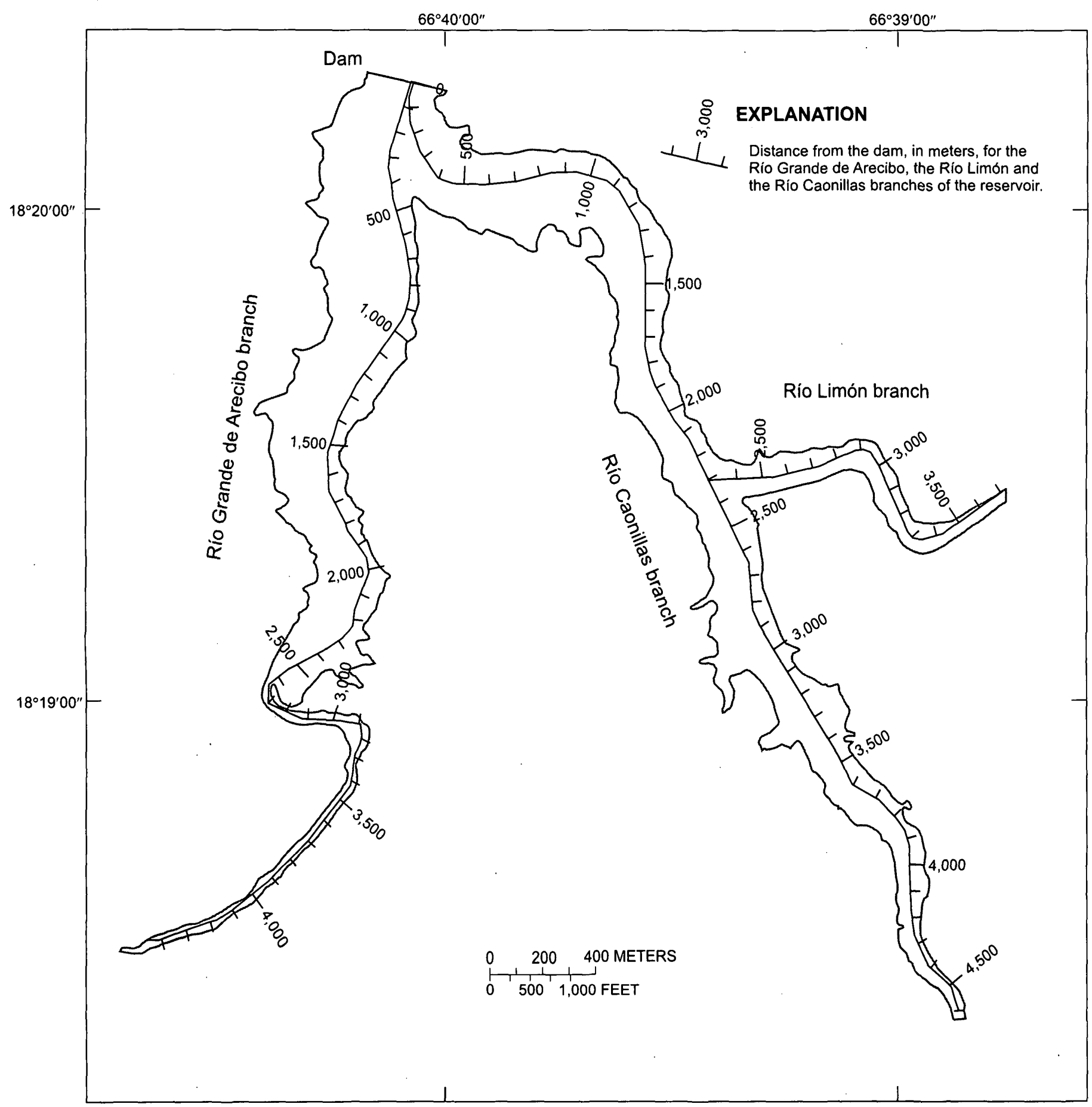

Figure 4. Reference distances for longitudinal profiles of Lago Dos Bocas, Puerto Rico, during the 1994, 1997, and 1999 bathymetric surveys. 


\section{ACTUAL CAPACITY AND SEDIMENT ACCUMULATION}

About 52 percent, or 19.46 million cubic meters, of the original storage capacity of Lago Dos Bocas has been lost because of sediment accumulation. The storage capacity of Lago Dos Bocas has decreased considerably (about 15 percent) over the last 5 years and 9 percent of the total original storage capacity since construction (table 2). In 1994, the storage capacity was 21.31 million cubic meters, decreasing to 20.23 million cubic meters in 1997 (Soler-López and Webb, 1998), and to 18.04 million cubic meters in 1999. This accelerated storage capacity loss in the last part of the decade can be attributed primarily to two major storms, Hurricane Hortense in September 1996 and Hurricane Georges in September 1998. These storms brought intense rainfall, and the runoff entering Lago Dos Bocas was extremely high, mobilizing large amounts of sediments into the reservoir. Peak discharges measured at the Río Grande de Arecibo below Utuado gaging station (no. 50024950) were 733 and 2,163 cubic meters per second for Hurricane Hortense and Hurricane Georges, respectively. Additional runoff entering the reservoir on the Río Limón and Río Caonillas tributaries was not measured. Of the 19.46 million cubic meters of the sediment accumulated between 1942 and 1999, 3.27 million cubic meters or 16.8 percent $[(3.27 \div 19.46) \mathrm{x}$ $100=16.8$ ] has occurred in the last 5 years primarily because of the two storms mentioned above. The most probable scenario is that most of the recent sediment accumulation between 1994 and 1999 actually occurred between 1996 and 1998.

Although several bathymetric surveys of Lago Dos Bocas have been conducted in the past, the purpose of this report is to evaluate the impact of the two major storms on the storage capacity of the reservoir, so only the results of the latest three surveys are presented (table 2). Selected cross sections. representing the reservoir bottom from shore to shore are presented in figure 5 .

Table 2. Summary of the 1994, 1997, and 1999 bathymetric survey results, Lago Dos Bocas, Puerto Rico

\begin{tabular}{|c|c|c|c|}
\hline & 1994 & 1997 & 1999 \\
\hline Total capacity, in millions of cubic meters & 21.31 & 20.23 & 18.04 \\
\hline Live storage, in millions of cubic meters & 19.15 & 18.68 & 17.06 \\
\hline Dead storage, in millions of cubic meters & 2.16 & 1.55 & 0.98 \\
\hline Years since construction & 52 & 55 & 57 \\
\hline Sediment accumulated, in millions of cubic meters & 16.19 & 17.27 & 19.46 \\
\hline Storage loss since construction, in percent & 43 & 46 & 52 \\
\hline Annual loss of capacity, in percent & 0.83 & 0.84 & 0.91 \\
\hline Intersurvey sedimentation rate, in millions of cubic meters per year & 0.321 & 0.367 & 1.09 \\
\hline Long-term sedimentation rate, in millions of cubic meters per year & 0.311 & 0.314 & 0.341 \\
\hline Year the reservoir is projected to fill & 2062 & 2061 & 2052 \\
\hline Sediment yield, in megagrams per square kilometer per year ${ }^{1}$ & 1,000 & ${ }^{2} 1,299$ & 1,377 \\
\hline
\end{tabular}






Figure 5. Selected cross-section profiles generated from the TIN surface model of Lago Dos Bocas, Puerto Rico, based on 1994, 1997, and 1999 bathymetric surveys. Refer to figure 2 for cross-section loc ations. 


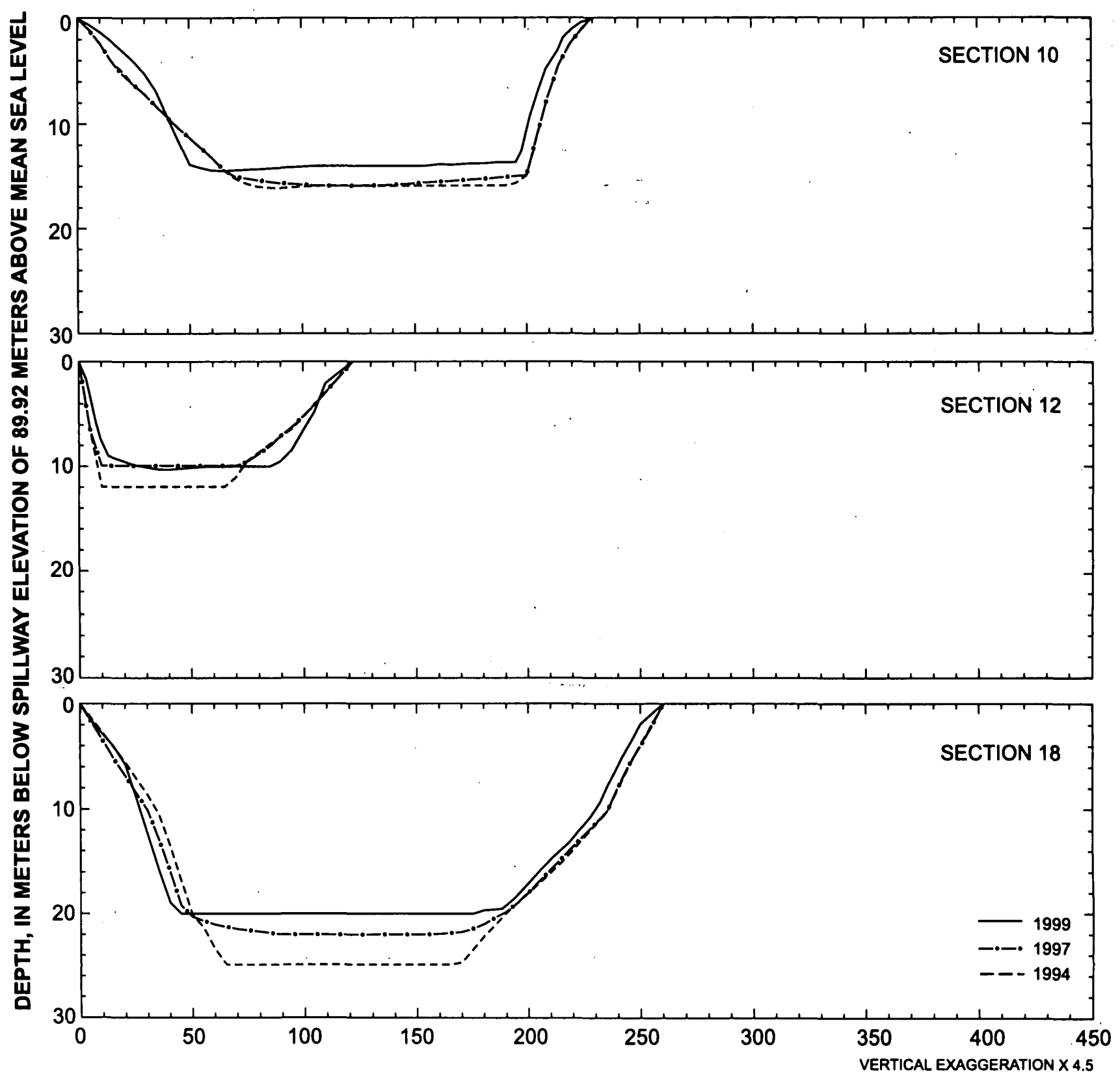

DISTANCE FROM LEFT BANK, IN METERS

Figure 5. Selected cross-section profiles generated from the TIN surface model of Lago Dos Bocas, Puerto Rico, based on 1994, 1997, and 1999 bathymetric surveys-Continued. Refer to figure 2 for cross-section locations. 


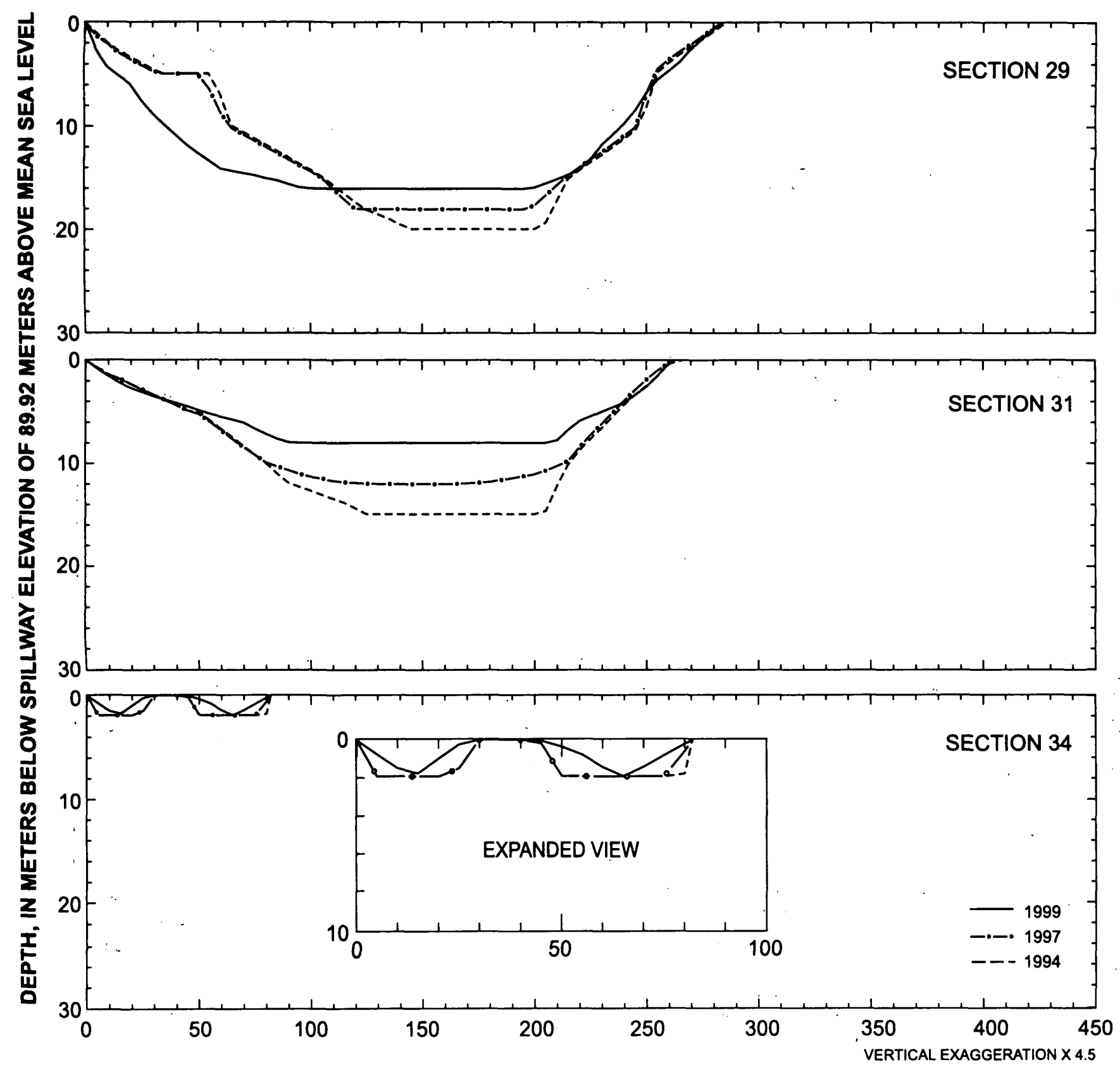

DISTANCE FROM LEFT BANK, IN METERS

Figure 5. Selected cross-section profiles generated from the TIN surface model of Lago Dos Bocas, Puerto Rico, based on 1994, 1997, and 1999 bathymetric surveys-Continued. Refer to figure 2 for cross-section locations. 


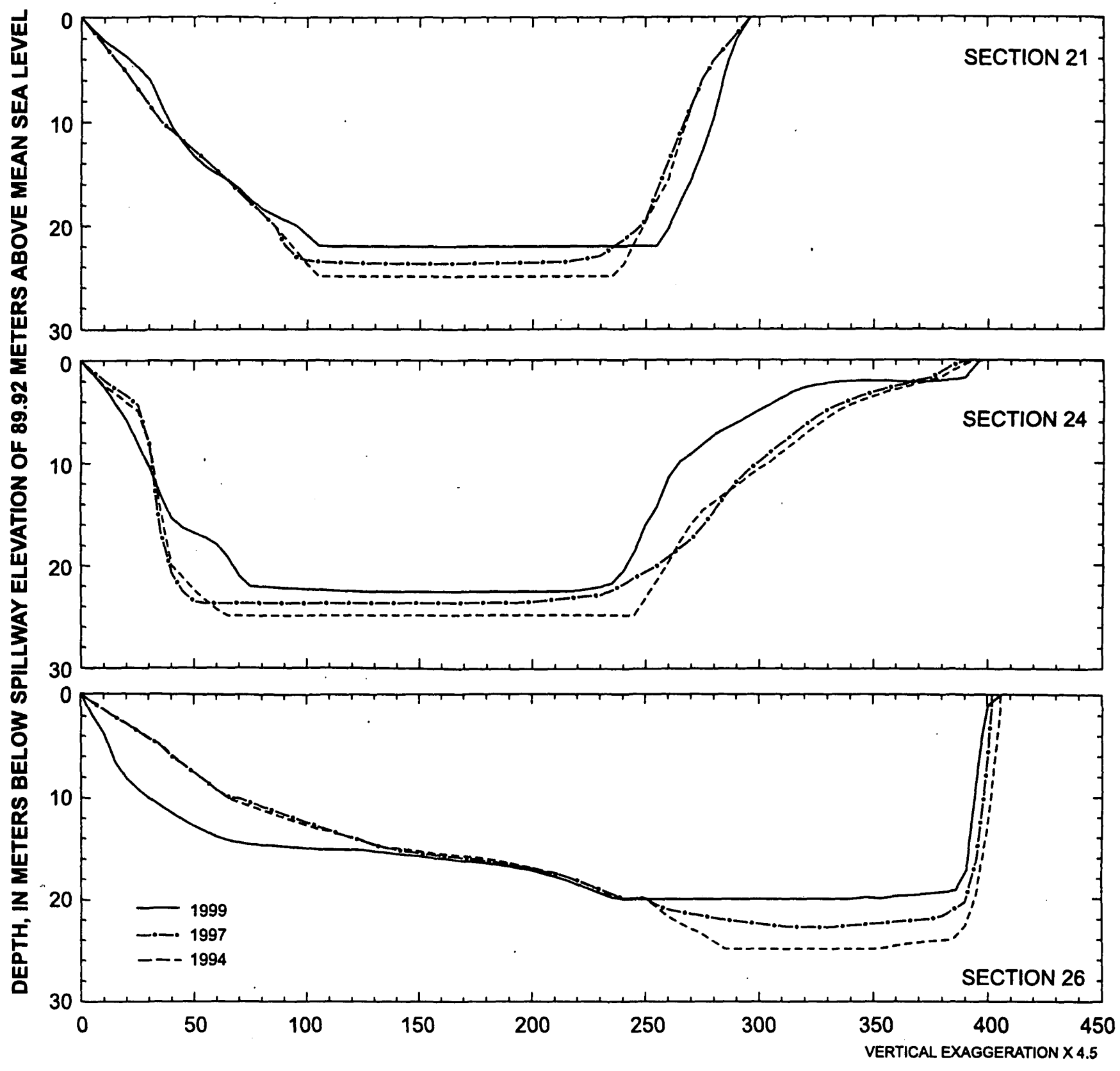

DISTANCE FROM LEFT BANK, IN METERS

Figure 5. Selected cross-section profiles generated from the TIN surface model of Lago Dos Bocas, Puerto Rico, based on 1994, 1997, and 1999 bathymetric surveys-Continued. Refer to figure 2 for cross-section locations. 


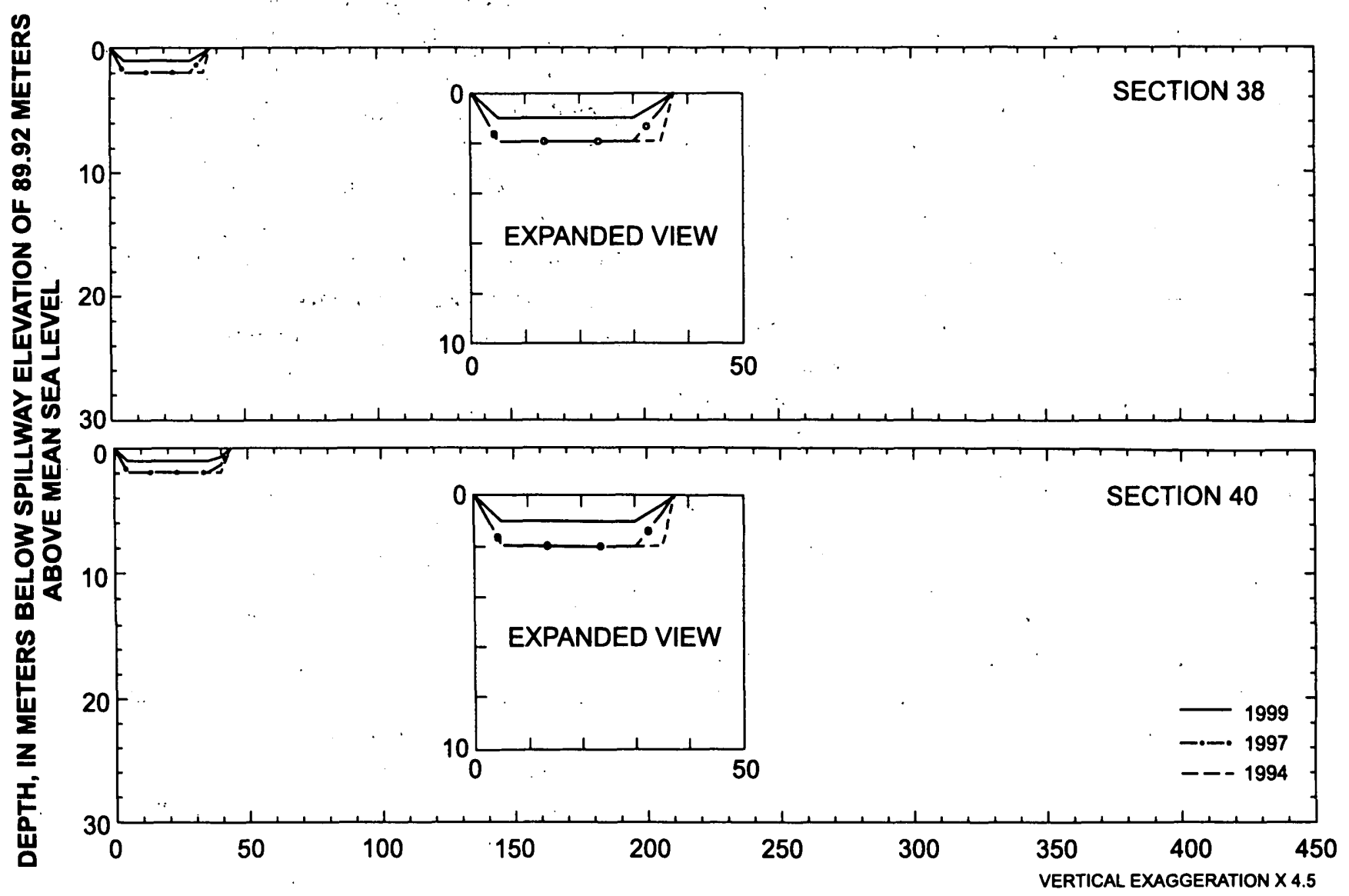

DISTANCE FROM LEFT BANK, IN METERS

Figure 5. Selected cross-section profiles generated from the TIN surface model of Lago Dos Bocas, Puerto Rico, based on 1994, 1997, and 1999 bathymetric surveys-Continued. Refer to figure 2 for cross-section locations. 
Longitudinal profiles along the Río Grande de Arecibo, Río Caonillas and Río Limón branches of the reservoir are shown in figure 6 . These cross sections were generated from the TIN surface models of Lago Dos Bocas for the corresponding years. Although minor discrepancies may be related to survey resolution, the general trends of sediment accumulation and scour are evident.

Most of the sediment accumulation in the reservoir has occurred in the Río Grande de Arecibo branch. From 1994 to 1997, an average of about 2 meters accumulated in this area. An additional layer of sediment with an average thickness of 2 meters has accumulated in the same area since 1997. In the Río Caonillas branch, there has been minimal sediment deposition, confirming that Lago Caonillas upstream is an effective sediment trap (Soler-López and Webb, 1998). Sediment accumulation is only noticeable downstream of the confluence of Río Caonillas and Río Limón branches (fig. 2). Here, an average of about 1.5 meters has accumulated since 1997. In the Río Limón branch, no deposition is noticeable since 1997 based on the data presented in figure 5. However, from 1994 to 1997 about 1 meter of sediment accumulated. This relatively low sediment accumulation rate may be the result of high water velocities generated from the Hurricane Georges runoff, promoting sediment bypass in this branch of the reservoir. Deposition probably occurred further downstream.

Capacity curves for 1994, 1997, and 1999 were generated from the respective TIN's (fig. 7) by calculating the reservoir volume at 0.3048 -meter (1 foot) intervals. A storage capacity table for October 1999 is presented in table 3 . The dead storage (that volume below the crown elevation of the penstocks) of Lago Dos Bocas has been reduced from 2.16 million cubic meters in 1994 to 0.98 million cubic meters in 1999 , reducing the available dead storage by 45 percent in 5 years.

\section{TRAPPING EFFICIENCY AND SEDIMENT YIELD}

The trapping efficiency of Lago Dos Bocas was estimated using the capacity/inflow ratio described by Brune (1953) who developed a curve that estimates the trapping efficiency of a reservoir based on the relation between the reservoir volume and the mean annual inflow to the reservoir. This curve has three components or sub-curves: one for highly flocculated and coarse-grained material, another for primarily colloidal and dispersed fine-grained material, and a median curve for a combination of materials. Particlesize analysis was not performed on the reservoir's bottom sediments, and so Brune's (1953) median curve was used. On the basis of the 1999 storage capacity of 18.04 million cubic meters and a mean annual runoff of $\mathbf{4 0 0}$ million cubic meters (Quiñones and others, 1989), the storage capacity/inflow ratio for 1999 is 0.045 . Interpolating this value in Brune's curve (fig. 8), the trapping efficiency is currently about 73 percent. This means that under normal conditions and without operating drainage structures of the reservoir, about 73 percent of the sediment entering the reservoir remains in the reservoir, and the other 27 percent is either spilled over the dam or discharged through the power generating ducts. Using the Brune (1953) curve (fig. 8), the 1942 trapping efficiency was 87 percent, giving an average long-term trapping efficiency of about 80 percent.

Sediment yield has been defined by the American Society of Civil Engineers as the total sediment outflow from a catchment or drainage basin, measurable at a point of reference and during a specified period of time per unit of surface area (McManus and Duck, 1993). The amount of sediment accumulated in the reservoir (19.46 million cubic meters) divided by the long-term average trapping efficiency of the reservoir ( 80 percent) and by the net sediment-contributing drainage area of the reservoir (310 square kilometers) gives the quantity of sediment eroded from the basin per unit of area $(78,468$ cubic meters per square kilometer). This, in turn, divided by the number of years since impoundment (57) gives the sediment yield of the reservoir basin. Assuming a drybulk density of one gram per cubic centimeter, the estimated sediment yield of the Lago Dos Bocas drainage area is about 1,377 megagrams per square kilometer per year for 1999. 


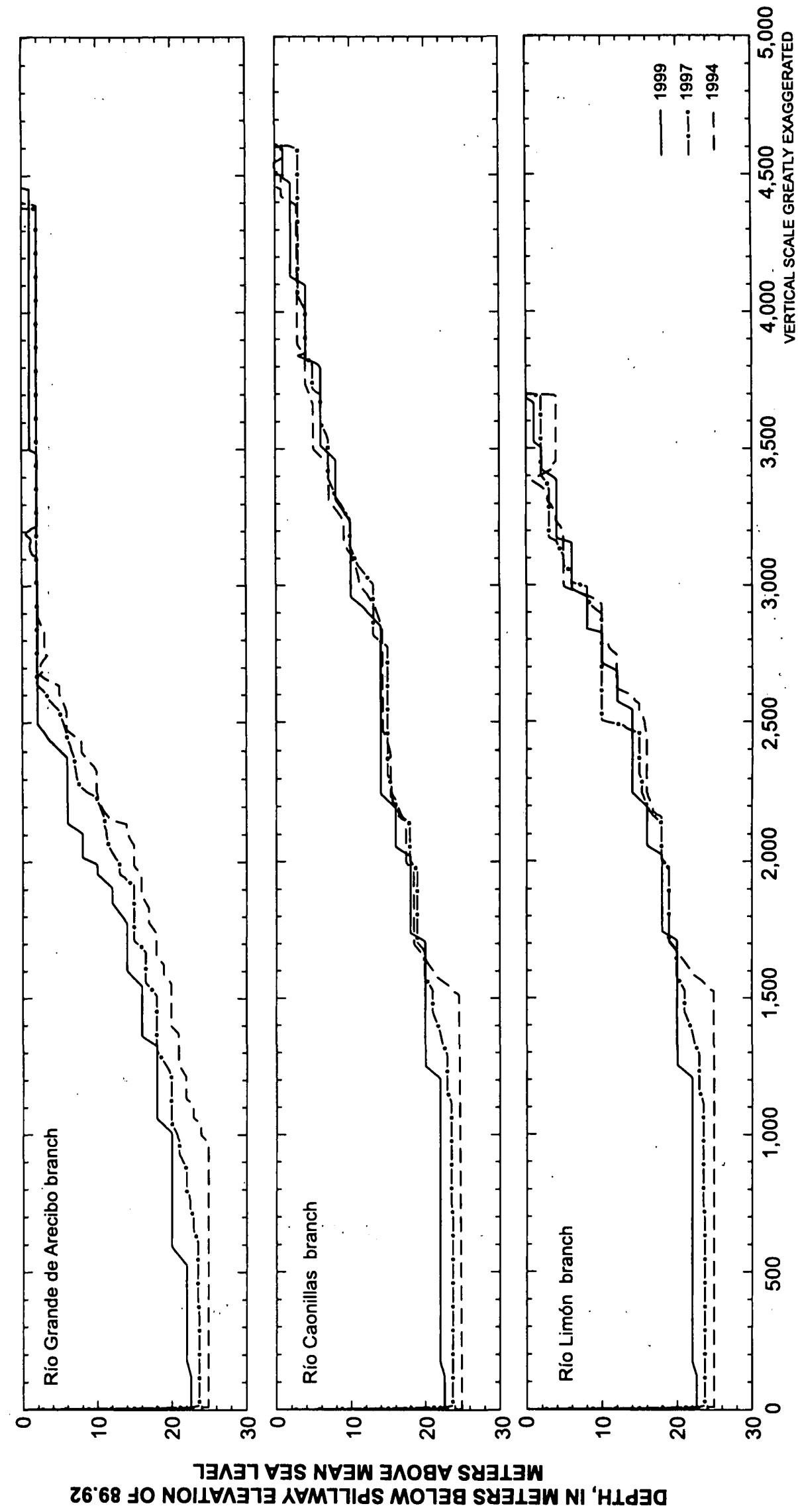

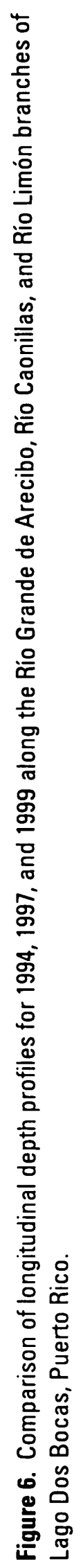




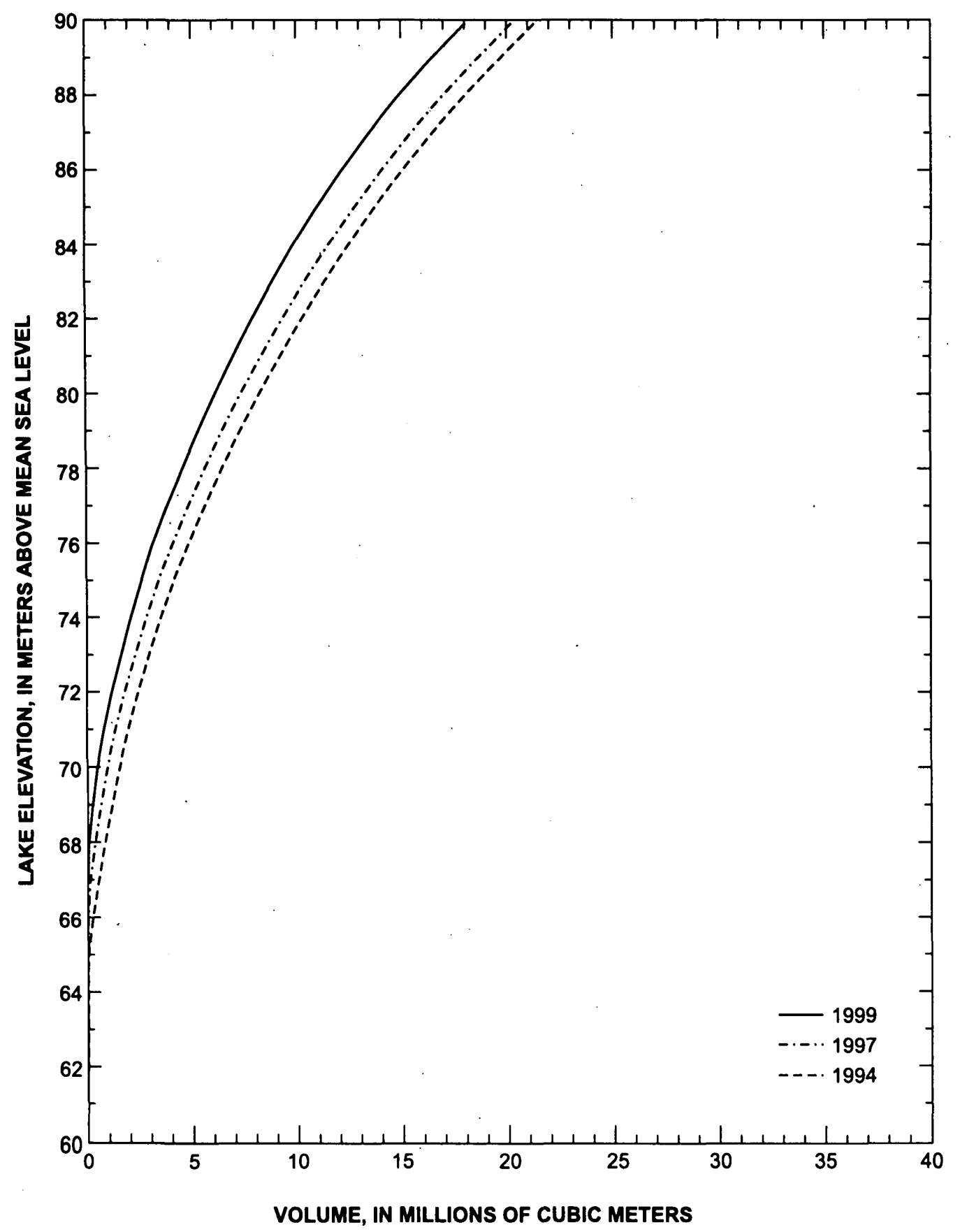

Figure 7. Lake elevation-storage capacity curves for Lago Dos Bocas, Puerto Rico, for 1994, 1997, and 1999. 
Table 3. Available storage capacity, as a function of lake elevation, for Lago Dos Bocas, Puerto Rico, October 1999

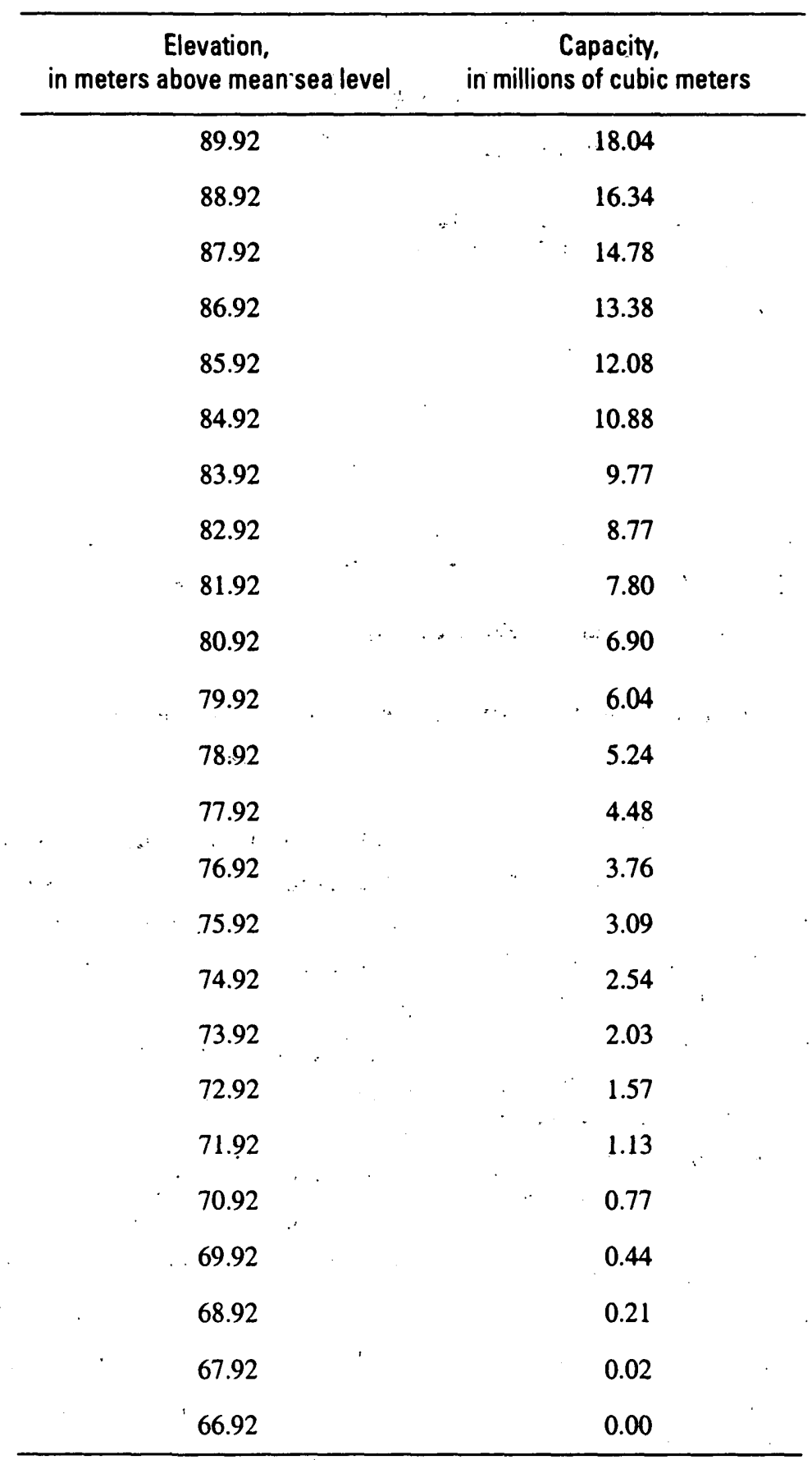






Figure 8. Storage capacity to inflow relation established by Brune (1953).

The reported 1997 sediment yield of the reservoir catchment of 1,000 megagrams per square kilometer per year (Soler-López and Webb, 1998) is conservative, because this estimate only takes into account the sediment deposited in the reservoir and not the sediment that passes through the powergenerating intake and over the spillway during flood events. To standardize the 1997 and 1999 results, the 1997 sediment yield was adjusted by using the trapping efficiency of Lago Dos Bocas derived from the 1997 survey ( 78 percent). Based on the average long-term trapping efficiency of Lago Bos Bocas for 1997, the corrected sediment yield of the reservoir catchment is about 1,299 megagrams per square kilometer per year for 1997. This represents an increase of about 78 megagrams per kilometer per year or 6 percent from 1997 to 1999.

The storm-accelerated sedimentation rate of Lago Dos Bocas has reduced the estimated useful life of the reservoir to about 53 more years (or by the year 2052) before it completely fills with deposited material. Although the recurrence rate of a stormaccelerated sedimentation cannot be accurately predicted, frequent recurrence is possible because many tropical storms threaten the island of Puerto Rico, and floods occur every year. However, it is reasonable to assume that the storm-accelerated sedimentation rate represents the worst-case scenario in terms of useful life of the reservoir. Moreover, this estimate does not take into account the decrease in trapping efficiency that occurs as a reservoir fills with sediments, which slows the filling process.

In any case, the life expectancy of the reservoir was reduced considerably by sediment deposition that occurred during recent hurricane-induced floods. Without better erosion control in the drainage basin, future hurricanes will rapidly fill Lago Dos Bocas. 


\section{REFERENCES}

Brune, G.M., 1953, Trap efficiency of reservoirs:

Transactions of the American Geophysical Union, v. 34 , no. 3 , p. $407-418$.

Environmental Systems Research Institute, Inc., 1992, Surface modeling with TIN, surface analysis and display: Redlands, Cal., 8 chapters.

McManus, J., and Duck, R.W., eds., 1993, Geomorphology and sedimentology of lakes and reservoirs: Chapter 6, Reservoir sedimentation rates in the Southern Pennine Region, UK: John Wiley \&'Sons, p. 73-92.

Quiñones, Ferdinand, Meléndez, Frank, and Bonnet, Carlos, 1989, Sedimentation survey of Lago Dos Bocas, Puerto Rico, June 1985: U.S. Geological Survey Open-File Report 86-241, 14 p.
Sheda, H.E., and Legas, James, 1968, Condition of concrete dams in Puerto Rico, in section 5, in Condition of Dos Bocas Dam, Puerto Rico: U.S. Department of the Interior, Bureau of Reclamation, Chapter 17, 17 p., 6 pls.

Soler-López, L.R., and Webb, R.M.T., 1998, Sedimentation survey of Lago Dos Bocas, Puerto Rico, June 1997: U.S. Geological Survey WaterResources Investigations Report 98-4188, 14 p., 2 pls. 
District Chief

Caribbean District

U.S. Geological Survey

Water Resources Division

GSA Center, Suite 400-15

651 Federal Drive

Guaynabo, Puerto Rico 00965-5703 